\title{
Face-to-Face and Remote Learning During the Confinement Due to Covid19: The Experience of Higher Education Students
}

\author{
Fátima Leal ${ }^{1(\bowtie)}$ and Maria Elisa Chaleta ${ }^{2}$ \\ ${ }^{1}$ Center for Research in Education and Psychology, University of Évora, Portugal \\ ${ }^{2}$ Department of Psychology, University of Évora, Portugal \\ fhleal@uevora.pt
}

\section{ABSTRACT}

Due to COVID19 disease contingencies, in several countries, universities were forced to replace the face-to-face classes for a non-face-to-face system, also called as Emergency Remote Teaching - ERT. In this scenario, both teachers and students experienced several challenges and had to adapt to new ways of teaching and learning. The goal of this study was to understand how students experienced this situation. Through a qualitative methodology, we interviewed eight higher education students from social sciences scientific areas. Thematic analysis was used to identify and interpret patterns and themes in students' responses. Results show that students experimented several difficulties at different levels: cognitive level (e.g., attention, concentration, and information storage), motivational (e.g., demotivation to study), tiredness; organizational (e.g., time and tasks management), and social level (e.g., interpersonal relationship and lack of contact with people). These results bring new knowledge to this problematic area and can be useful for students, teachers, and higher education institutions.

Keywords: difficulties, experiences, higher education, non-face-to-face classes, students

Cite this article as: Leal, F., \& Chaleta, ME. (2020). Face-to-Face and Remote Learning During the Confinement Due to Covid19: The Experience of Higher Education Students. International Journal of Higher Education Pedagogies, 1(1), 30-35. https://doi.org/10.33422/ijhep.v1i1.19

\section{Introduction}

Since COVID-19 was reported by Wuhan health authorities on 31st December 2019, the world begone a new chapter of its history. A lot of measures, encompassing various areas of society like health, education, and economy, have been adopted around the world. Since $4^{\text {th }}$ March 20 Portugal reported the first cases of this disease, and the constraints started.

"According to UNESCO, more than 160 countries implemented nationwide closures, which impacted over $87 \%$ of the world's student population (...) millions of additional learners will experience education disruption" (Araújo, Lima, Cidade, Nobre, \& Neto, 2020, p.1).

In Portugal, the most universities replaced the face-to-face for a non-face-to-face class regime, through the online approach, with classes functioning on a videoconference system.

The big challenge in this pandemic situation was the requirement for a rapid adaptation to three different need experiences: the need for confinement in which physical and social distance were imposed; the need to get used to a virtual classes system in which students and teachers suddenly found themselves confronted with the university inside their screens; and the need to acquire and use technological skills to deal with a whole range of tools like computer systems, software, platforms, and applications.

Although most of the population started to call this new system as "distance learning" researchers and several professionals of traditional "distance learning" - this already well established and recognized in our country - reacted against this wrong use of the concept. 
The disagreement was that this abrupt shift that the education systems took on, when switching the face-to-face classes to a non-face-to-face class regime, it should not be called as distance education, but it should have a different designation: Emergency Remote Teaching - ERT (Pedro, 2020). This kind of teaching, already implemented in many other countries in situations of natural disasters and other calamities, it is an alternative way to avoid the interruption of training and to maintain the relation between students and educational institutions.

In other crisis situations, for example, in the United States, in August 2005, in the context of Hurricane Katrina, in which thousands of people had to be evacuated (Hoover, Dopson, \& Drehobl, 2010); in New Zealand, at the time of the Christchurch earthquake in 2011 (Mackey et al, 2012); in Afghanistan, multiple situations of violence and conflict forced the suspension of classes, and used alternative systems such as radio and DVDs to guarantee continued access to education (Davies \& Bentrovato, 2011); in Syria, in response to displacement during the conflict, the use of EdTech - Educational Technology (Tauson \& Stannard, 2018).

Hodges, Moore, Lockee, Trust and Bond (2020) refers to the ERT as an unexpected form of education that emerges on the sequence of a catastrophe and as an alternative to the traditionally classic, physical, and face-to-face learning system. Generally, this kind of teaching emerges to reply to an unpredicted need, and must have a quick, temporary, and reliable answer (Mohmmed, Khidhir, Nazeer, \& Vijayan, 2020).

According to Pedro (2020), the ERT must happen quickly and meet a minimum of requirements. It is more oriented to the figure of the teacher than to the learning process and focuses more on teaching practices than learning practices. It is largely restricted to technology and synchronous format, based on the transposition of activities that would be done in person for online teaching. This can have implications on the quality of teaching.

One of the assumptions of the ERT it is the provisional character. Thus, once the circumstances of crisis and catastrophe disappear or decrease in intensity, the teaching regime must return to its original state (Mohmmed, Khidhir, Nazeer, \& Vijayan, 2020).

But while the situation persists, for students, the need to adapt to a sudden change in the way of learning, and to adopt new methods of study, leads to the emergence of various affective, cognitive, and metacognitive experiences, specifically some difficulties that can be hard for students to deal with.

Alvarez (2020) interviewed five students, in the Philippines, to understand their experiences during this ERT situation. He found four main themes that revealed to be more challenging: poor to no internet access, financial constraints, lack of technological devices, and affective or emotional support.

Being aware that culture and different countries realities are important, the aim of our study was to understand what these difficulties were in our Portuguese higher education context.

\section{Methods}

This study fits into a qualitative methodological perspective. This research is a small part of a bigger investigation about affective, cognitive, and metacognitive experiences of higher education students during COVID19 Confinement. The aim of this study was to understand the difficulties that students felt when they had to change from the face-to-face teaching model to the non-face-to-face teaching format. Our sample involved eight voluntary Portuguese students from the $2^{\text {nd }}$ and $3^{\text {rd }}$ years of undergraduate courses at the School of Social Sciences (Psychology, Education and Management Sciences). First, they signed a 
consent term with explanations about procedures. Because we intend to do an exploratory study and our sample was so small it was constituted a unique group.

We used a semi-structured interview guide to collect information. Participation was anonymous. Interviews were made via online, recorded, and transcribed. To analyze students' answers, we used the thematic content analysis technique, according to Bardin (2008).

\section{Results}

Results showed that students experimented several difficulties at different levels: cognitive level (e.g., attention, concentration, and information storage); motivational (e.g., tasks performance); tiredness; organizational level (e.g., time and tasks management); social level (e.g., interpersonal relationship and lack of contact with people) and difficulties in dealing with different roles (student at home versus "son/daughter").

At the cognitive level, students' verbalizations referred to difficulties related to the needs: of paying attention during online classes, of maintaining the concentration to focus on several tasks and to retain information.

"(...) the classes are followed and that costs so much because we have one theoretician (...) and right after that we are having another (...) we have those two and they are very theoretical and (...) we have to be attentive and (...) it is a difficult discipline with a lot of little things, and I cannot be inattentive" (S.1)

"The difficulty I feel... is not so much having difficulty in carrying out the tasks but having difficulty to focus on and doing them with attention (...)" (S.2)

“(Difficulties) In retaining information... in being attentive (...)" (S.3)

"(Difficulties) to assimilate all information" (S.4)

At the level of personal organization, students referred some difficulties when they had to manage their time (trying to distribute tasks for the available time). This difficulty emerged because students perceived a higher workload demanded by teachers.

"(...) Our day continues to have 24 hours (...) and I think that many teachers are not understanding this and are overloading it so much... that we have reached a time when we no longer know what to do..." (S.4)

"We have a big workload... what teachers demand...they think that we have more time because we are not there [at university] in person ...but we have several disciplines (...) and we have much more work to do" (S.6)

Difficulties in terms of motivation emerged in terms of carrying out tasks (when comparing to face-to-face classes system), but they also appeared reflected in the difficulty in outlining short-term work goals.

"Difficulties (...) in establishing weekly or daily goals" (S.3)

"Performing the tasks (...) with as much motivation as I would have done before" (S.2)

One of the other difficulties pointed out referred to the increased tiredness that students verbalized when comparing this non-face-to-face classes system with the face-to-face system.

"I get really tired" (S.1)

"I get more tired (...)" (S.5) 
One of the other difficulties was the feeling of lack of proactivity versus expenditure of energy; that is, the feeling that, much more effort was necessary to obtain the same level of quality in carrying out academic work.

"My biggest difficulties are having the same level of proactivity and quality... because the quality, in the end, it may be the same or not, I don't know, but in terms of the cost and energy expenditure is much higher" (S.3)

"It seems that (...) academic tasks are more difficult to do... they take longer..." (S.5)

The difficulty in terms of interpersonal relationships emerged in a verbalization that highlighted the lack of contact with people, colleagues, teachers, friends, as a demotivating factor to perform academic tasks.

"We don't have direct contact with people" (S.5)

“(...) normally [in face-to-face classes] I am attentive during classes and I like to participate in classes, and now I feel that this is not happening... [before] I usually spoke something in classes, but now, I don't know... it's difficult" (S.3)

Some students referred difficulties in dealing with different roles once they had to be at home (student at home versus "son/daughter")

“(...) It was a little complicated at first because, in addition to managing all this habituation, moving for a space that was previously associated with leisure and rest [my home], now is for studying and working and it is necessary to be concentrated... add this to my mother to understand that I'm not on vacation... I have work (and a lot more work with this transition from face-to-face classes to non-face-to-face classes)" (S.2)

\section{Conclusion}

With this study it was possible to understand that due to COVID19 constraints, the face-toface classes were replaced by non-face-to-face classes and, this alternative way of teaching (ERT) has provoked several differences on the habits of study and learning on higher education students.

This situation led to new experiences (affective, cognitive, and metacognitive). The feeling of difficulty was present on their speech. Through interviews it was possible to understand some of these experiences, namely, what were the biggest difficulties they felt.

The most frequently mentioned category has a cognitive nature and concerns to attention and concentration in class, and during the study process. Information retention was mentioned when students felt they had difficulties in memorizing the new information.

At the motivational level performing academic tasks was referred as difficult; tiredness was related to many sitting time and looking at the pc screen; on the personal organizational level, the time and tasks management were mentioned by students. At the social level, interpersonal relationships, and lack of contact with people were referred by almost all students. Difficulties in dealing with different roles were not so much referred but it is understandable that, when students are at home, with family, they have a double role as "son/daughter/brother/sister" but also "student" who has to perform like it, because they have "online classes" with their teachers on the other side of the screen. When families do not understand this topic and are always asking for help or demanding from the young, students have difficulty separating these two positions and feel that they are on a "double son-student role" and it is not easy to accomplish any of the two facets. 
Although our small sample and the limitation on generalizing this data, these results can be useful for students once they can understand that they are not alone and that "these feelings are similar and there are a lot of students in the same situation". Therefore, this feeling can be comforting for students (avoiding the despair and mental health problems).

We agree with Garcia, Silva, Veraszto and Amaral (2016) when they defend that "a simple transposition of the dynamics of the classroom to the virtual environment is not enough and it is necessary to understand the logic of these new communication technologies, their own language, characteristic time, resources and, thus, create or adapt teaching methods" (p.1190).

So, these findings can be useful for teachers once that if they can understand the "opposite side of the wall" (the students' perspective), this can bring new cues to change their pedagogical practices.

We also agree with Maslov (2020) when he writes that "The analysis of ERT results can give important insights into the workings of the existing educational processes and can help assess the level of the educational systems' resilience" (p.30).

Therefore, these results can also be useful for Higher Education Institutions once they can provide facilitating politics that can help students to deal with those situations, for instance, creating new helping programs like Online Study (Chaleta, Leal \& Campos, 2020).

\section{Acknowledgment}

This paper is an output of the science project Learning and Teaching at the University" PTDC/CED-EDG/29252/2017and it is financed by national founds by FCT - Foundation for Science and Technology, I.P.

\section{References}

Alvarez, A. Jr. (2020). The phenomenon of learning at a distance through emergency remote teaching amidst the pandemic crisis. Asian Journal of Distance Education, vol.15, no.1, pp. 144-153. https://doi.org/10.5281/zenodo.3881529

Araújo, F.J.O, Lima, L.S.A., Cidade, P.I.M., Nobre, C.B. and Neto, M.L.R. (2020). Impact Of Sars-Cov-2 And Its Reverberation in Global Higher Education and Mental Health, Psychiatry Research, vol. 288, pp.112977. ISSN 0165-1781.

Bardin, L. (2008). Análise de conteúdo. Edições 70, Lisboa, Portugal

Chaleta, E., Leal, F. and Campos, M. (2020). Online study - um programa de suporte ao estudo e aprendizagem de estudantes de ensino superior. $10^{a}$ Conferência Forges. O ensino superior na era digital nos países e regiões de língua portuguesa: desafios e propostas. 1820 Novembro de 2020.

Davies, L. and Bentrovato, D. (2011). Understanding education's role in fragility: synthesis of four situational analyses of education and fragility: Afghanistan, Bosnia and Herzegovina, Cambodia, Liberia. IIEP research papers. International Institute for Educational Planning, Paris

Eder, R. (2020). The Remoteness of Remote Learning: A Policy Lesson from COVID19. Journal of Interdisciplinary Studies in Education, vol.9, no. 1, pp. 168-171. ISSN: 26900408. https://doi.org/10.32674/jise.v9i1.2172 
Garcia, A.O., Silva, R.A., Veraszto, E.V. and Amaral, E.F. (2016) Education for innovation: construction of a competency-based profile, Edulearn16, Proceedings, pp. 192-201. https://doi.org/10.21125/edulearn.2016.1033

Hodges, C., Moore, S., Lockee, B., Trust, T. and Bond, A. (2020). The diference between emergency remote teaching and online learning. EDUCAUSE. Rev. https://er.educause.edu/articles/2020/3/the-difference-between-emergency-remote-teachingand-online-learning. Accessed 23 March 2020

Hoover, M., Dopson, S. and Drehobl, P. (2010). Working with local, state and federal Partners to address Health education needs of Hurricane Katrina evacuees in Houston: a CdC Case study. American Journal of Health Education, vol. 41, no.2, pp. 124-126. https://doi.org/10.1080/19325037.2010.10599136

Mackey, J., Gilmore, F., Dabner, N., Breeze, D. and Buckley, P. (2012). Blended learning for academic resilience in times of disaster or crisis. Journal of Online Learning and Teaching 8(2), 122-135. http://hdl.handle.net/10092/16294

Maslov, Y.V. (2020). Lessons Learned from Emergency Remote Teaching during the COVID-19 Pandemic. International Journal of Education and Science, 3(2). https://doi.org/10.26697/ijes.2020.2.17

Mohmmed, A. O., Khidhir, B. A., Nazeer, A. and Vijayan, V. J. (2020). Emergency remote teaching during Coronavirus pandemic: the current trend and future directive at Middle East College Oman. Innovative Infrastructure Solutions, 5(72), 1-11. https://doi.org/10.1007/s41062-020-00326-7

Pedro, N. (2020). Webinário Ensino Online em Situação de Emergência: Analisar o Passado, Planear o Futuro. Disponível em: https://www.youtube.com/watch?v=CD4_ c64cLFE\& $=332 \mathrm{~s}$

Tauson, M. and Stannard, L. (2018). EdTech for learning in emergencies and displaced settings: a rigorous review and narrative synthesis. Save The Children, London.

United Nations Educational, Scientific and Cultural Organization. (2020). Distance learning solutions. Retrieved from https://en.unesco.org/covid19/educationresponse/solutions. 